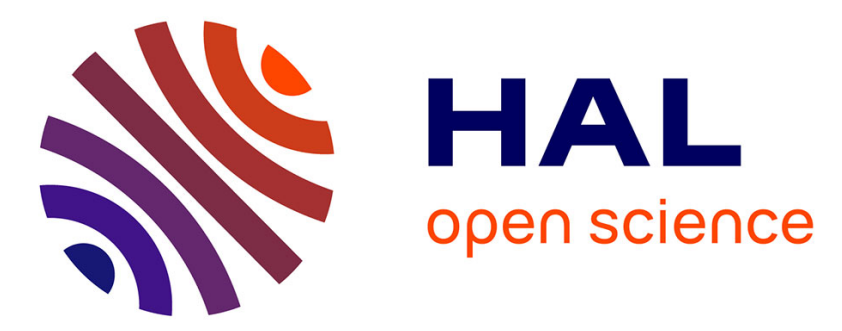

\title{
Effect of protein glycation in the presence or absence of wheat proteins on detection of soybean proteins by commercial ELISA
}

Céline Platteau, Tatiana Cucu, Bruno de Meulenaer, Bart Devreese, Marc de Loose, Isabel Taverniers

\section{To cite this version:}

Céline Platteau, Tatiana Cucu, Bruno de Meulenaer, Bart Devreese, Marc de Loose, et al.. Effect of protein glycation in the presence or absence of wheat proteins on detection of soybean proteins by commercial ELISA. Food Additives and Contaminants, 2011, 28 (2), pp.127. 10.1080/19440049.2010.539627 . hal-00661253

\section{HAL Id: hal-00661253 https://hal.science/hal-00661253}

Submitted on 19 Jan 2012

HAL is a multi-disciplinary open access archive for the deposit and dissemination of scientific research documents, whether they are published or not. The documents may come from teaching and research institutions in France or abroad, or from public or private research centers.
L'archive ouverte pluridisciplinaire HAL, est destinée au dépôt et à la diffusion de documents scientifiques de niveau recherche, publiés ou non, émanant des établissements d'enseignement et de recherche français ou étrangers, des laboratoires publics ou privés. 


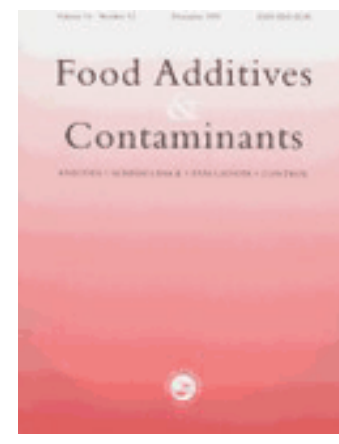

\section{Effect of protein glycation in the presence or absence of wheat proteins on detection of soybean proteins by commercial ELISA}

\begin{tabular}{|c|c|}
\hline Journal: & Food Additives and Contaminants \\
\hline Manuscript ID: & TFAC-2010-274.R1 \\
\hline Manuscript Type: & Original Research Paper \\
\hline $\begin{array}{r}\text { Date Submitted by the } \\
\text { Author: }\end{array}$ & 04-Nov-2010 \\
\hline Complete List of Authors: & $\begin{array}{l}\text { Platteau, Céline; Flemish Government, Institute for Agricultural and } \\
\text { Fisheries Research, Technology and Food Science Unit } \\
\text { Cucu, Tatiana; Ghent University, Department of Food Safety and } \\
\text { Food Quality; Ghent University, Department for Biochemistry and } \\
\text { Microbiology } \\
\text { De Meulenaer, Bruno; Ghent University, Department of Food Safety } \\
\text { and Food Quality } \\
\text { Devreese, Bart; Ghent University, Department of Biochemistry and } \\
\text { Microbiology } \\
\text { De Loose, Marc; Flemish Government, Institute for Agricultural and } \\
\text { Fisheries Research, Technology and Food Science Unit; Ghent } \\
\text { University, Department of Molecular Genetics } \\
\text { Taverniers, Isabel; Flemish Government, Institute for Agricultural } \\
\text { and Fisheries Research, Technology and Food Science Unit }\end{array}$ \\
\hline Methods/Techniques: & Immunoassays \\
\hline Additives/Contaminants: & Allergens \\
\hline Food Types: & \\
\hline
\end{tabular}

\section{SCHOLARONE \\ Manuscripts}




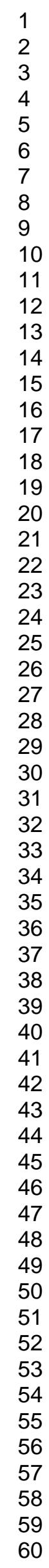 \\ Page 1 of 32}

1

2

4

5

6
7

8

10

11

12

14

15

16

17

18

19

20

22

23

25

26

27

29

30

32

33

34

35

36

(37

39

40

41

42

44

45

46

47

48

50

51

53

54

55

57

58

60

http://mc.manuscriptcentral.com/tfac Email: fac@tandf.co.uk 


\section{Effect of protein glycation in the presence or absence of wheat proteins on detection of soybean proteins by commercial ELISA}

Céline Platteau $^{\mathrm{a}, \mathrm{b}, \$}$, Tatiana Cucu ${ }^{\mathrm{a}, \mathrm{c}, \$}$, Bruno De Meulenaer ${ }^{\mathrm{a}^{*}}$, Bart Devreese ${ }^{\mathrm{c}}$, Marc De Loose $^{b, d}$, Isabel Taverniers ${ }^{b}$

${ }^{a}$ Department of Food Safety and Food Quality, Research Group Food Chemistry and Human Nutrition, Ghent University, Ghent, Belgium

${ }^{\mathrm{b}}$ Flemish Government, Institute for Agricultural and Fisheries Research (ILVO), Technology and Food Science Unit, Melle, Belgium

${ }^{\mathrm{c}}$ Department of Biochemistry and Microbiology, Laboratory for Protein Biochemistry and Biomolecular Engineering, Ghent University, Ghent Belgium

${ }^{\mathrm{d}}$ Department of Molecular Genetics, Ghent University, Ghent, Belgium

\$ These authors contributed equally

\footnotetext{
* Corresponding author: Ghent University, Coupure Links 653, B-9000, Belgium.

Tel.:+329264 61 66; fax: + 32926462 15. E-mail address: Bruno.DeMeulenaer@ UGent.be
} 


\section{Abstract}

Soybean (Glycine max) is the world's primary provider of protein and oil and is widely used in foodstuffs. However, the use of soybean in foodstuffs might pose a serious threat to

4 the allergic consumers since some proteins can cause allergic reactions. To date, mostly ELISA methods are used for testing contamination of foodstuffs with soybean. In view of the

6 complexity regarding allergen detection in foodstuffs and appropriate food product labelling, the aim of the present study was to investigate the impact of the Maillard reaction on the

8 detectability of soybean proteins using commercial ELISA kits. Accumulation of protein bound carbonyls, modification of reactive lysine residues and severe aggregation as a result of

10 incubation with glucose, in the presence or absence of soluble wheat proteins, were recorded. Moreover, detection of soybean proteins by means of three commercial ELISA kits was

12 strongly altered and was highly dependent on the type of kit used.

14 Keywords: Soybean allergy, Maillard reaction, ELISA, protein bound carbonyls, protein aggregation, reactive lysine. 


\section{Introduction}

Food allergy is an abnormal immunological response due to sensitization to a food component. With its increasing incidence over the last years, it represents an important health 20 problem, especially in industrialized countries, where it has been estimated to affect about $2 \%$ of the adult population and up to $8 \%$ of children (Monaci et al. 2006). Together with hen's

22 egg, cow's milk, fish, crustacea, peanut, tree nuts and wheat, soybeans belong to the 'big eight', being responsible for $90 \%$ of all allergic reactions (Report of the FAO 1995). It also 24 belongs to the list of 14 allergenic products which have to be declared on the label of a food product when present as an ingredient according to Directive 2007/68/EU (European 26 Parliament and Council Directive 2007/68/EC 2007).

Soybeans (Glycine max) contain about $35 \%$ of proteins and at least 21 proteins have 28 been shown to be IgE-reactive. Soybean allergy can occur as a result of primary sensitization, but can also be related to birch pollen allergy through structural similarities between the birch 30 pollen allergen Bet $v 1$ and the corresponding protein Gly $m 4$ in soybeans (secondary allergy) (Ballmer-Weber and Vieths 2008; Mittag et al. 2004). The symptoms associated with soybean 32 allergy are mostly mild, such as the Oral Allergy Syndrome (OAS), however, severe reactions have also been described (Foucard and Yman 1999; Kleine-Tebbe et al. 2002; Mittag et al. 34 2004). The incidence of soybean allergy has increased during the last years probably because more products are being produced with soybean (Wilson et al. 2005). Soybean is used as an 36 ingredient in a broad range of food products, both for its texturizing and nutritional benefits. Due to its diverse functional properties, such as water and fat absorption, emulsification, 38 foaming and gelation, soybean proteins are often included during food processing steps. However, extensive use of soybean proteins in foods might pose a serious threat to the 40 allergic consumers due to unintentional contamination which might take place during food 
processing. This can affect the safety of food products and lead to the presence of hidden allergens, therefore making avoidance diets increasingly challenging.

Various approaches have been applied to reduce the allergenicity of soybean proteins.

44 Enzymatic hydrolysis through fermentation is often applied to produce hypo-allergenic formulas, but is strongly dependent on the extent of the hydrolysis degree (Frias et al. 2008; Tsuji et al. 1997; Yamanishi et al. 1995). Reduction of soybean allergenicity has also been achieved by allergen conjugation with polysaccharides (Arita et al. 2001; Babiker et al. 1998).

48 Similarly, the impact of protein modifications occurring as a result of the multitude of chemical reactions occurring during food processing has been studied as well (Burks et al. 1991; Codina et al. 1998; Muller et al. 2000). In contrast to these studies focusing on the impact of soy protein modification on the antigenicity, only limited studies are available with

52 respect to the impact of these changes. In addition, the impact of these changes on the detectability using immunochemically methods, which are typically used by the industry and

54 enforcement agencies (Bando et al. 1998; Tsuji et al. 1995) has rarely been studied in a systematic manner for soybean protein.. The above-mentioned methods are based on antibody 56 - antigen interactions Therefore, immunoassays are subjected to complications due to the matrix effects, which may result in erroneous results. Moreover, the interaction of food 58 allergens with other food components, which are expected to occur during thermal processing, may lead to changes in the allergen structure and might hinder their detection by the

60 immunological methods. Therefore, it is important to gain knowledge on the influence of food processing on the tertiary structure of food allergens and the changes occurring at the amino 62 acid level as a result of chemical reactions taking place during processing. Moreover, information on the further impact of these changes on the allergenic potential and the 64 detectability of the allergens is invaluable. Van de Lagemaat et al. previously reported reductions of the antigenicity of soybean proteins after in vitro glycation using an in-house 
66 developed ELISA assay (de Lagemaat et al. 2007). In this study the impact of glycation in the presence or absence of other proteins on the detectability of soybean proteins by commercial

68 kits was investigated. A similar study on hazelnut proteins already showed that the detection was drastically affected as a result of protein glycation (manuscript submitted). 


\section{Materials and methods}

\section{Reagents and standards}

Soluble wheat proteins "Meripro 711" were kindly provided by Syral Belgium N.V.

74 (Aalst, Belgium). Chemicals and standards of analytical grade were obtained from SigmaAldrich (Bornem, Belgium), VWR (Leuven, Belgium) and Acros Organics (Geel, Belgium).

76 Solvents were of analytical grade from Chem-Lab (Zedelgem, Belgium), except for hexane which was of technical grade. Gel and standards for SDS-PAGE were from Bio-Rad

78 (Nazareth, Belgium) while the Krypton protein stain was provided by Thermo Scientific (Aalst, Belgium). The commercial ELISA kits used were Veratox ${ }^{\circledR}$ Soy Allergen (Neogen, 80 Lansing, USA), BioKits Soya Allergen Assay (Tepnel, Flintshire, UK) and Soy Residue (ELISA Systems, Queensland, Australia).

\section{Soybean protein extraction}

Soybeans were provided by Alpro (Wevelgem, Belgium) and Cargill (Mechelen, 84 Belgium). A mixture was made by taking equal amounts of each kind. Soybeans were frozen with liquid nitrogen and ground in a two-step process, first with a blender (Moulinex, France) 86 and secondly with an Ultra Turrax t25 (IKA, Wilmington, US).

Soybean protein extracts were obtained according to the protocol described by Yeung et

88 al. with slight modifications (Yeung and Collins 1996). Briefly, $100 \mathrm{~g}$ of ground beans were defatted with four times $1 \mathrm{~L}$ technical hexane. After an overnight evaporation of the solvent at 90 ambient temperature, $10 \mathrm{~g}$ defatted powder was mixed with $100 \mathrm{ml}$ of extraction buffer and mixed at $4^{\circ} \mathrm{C}$ over night. Protein extraction buffer consisted of a $1 \mathrm{M} \mathrm{NaCl}, 1.47 \mathrm{mM}$ $92 \mathrm{KH}_{2} \mathrm{PO}_{4}, 2.7 \mathrm{mM} \mathrm{KCl}$ and $10 \mathrm{mM} \mathrm{Na}_{2} \mathrm{HPO}_{4}$. Sodium azide $0.2 \mathrm{~g} \mathrm{~L}^{-1}$ was added to the extraction buffer to avoid microbial growth. Further a mixture of protease inhibitors $(2 \mathrm{mM}$ 
94 ethylenediaminetetraacetic acid (EDTA), $5 \mathrm{mM}$ sodium diethyldithiocarbamate (DIECA), 0.5 $\mathrm{mM}$ benzamidine hydrochloride (BAHC) and $0.2 \mathrm{mM}$ phenylmethylsulfonyl fluoride

96 (PMSF)) was added to the extraction buffer in order to increase the stability of the protein isolates during extraction and storage (Bjorksten et al. 1980). The protein mixtures were 98 further centrifuged for $1 \mathrm{~h}$ at $4^{\circ} \mathrm{C}$ and $20000 \mathrm{~g}$ to separate the lees. Subsequently, the clear supernatants were dialyzed (Spectra/Por 3 membrane tubing, MWCO $3.5 \mathrm{kDa}$ ) using the same

100 extraction buffer containing only $0.137 \mathrm{M} \mathrm{NaCl}$, for $48 \mathrm{~h}$ at $4^{\circ} \mathrm{C}$ and then filtered through a $0.45 \mu \mathrm{m}$ membrane filter (Puradisc FP 30, Novolab, Belgium). Finally, the protein solutions

102 were lyophilized and stored at $-20^{\circ} \mathrm{C}$ until further use. This extract will further on in this paper be considered as the reference extract.

\section{Maillard reaction in the absence of soluble wheat proteins}

Before treatment, soybean protein extracts were dialyzed against the $0.1 \mathrm{M}$ phosphate 106 buffer $\mathrm{pH} 7.4$ to remove the nitrogen containing additives (Spectra/Por 3 membrane tubing, MWCO $3.5 \mathrm{kDa}$ ). The reaction systems were prepared in the same phosphate buffer $\mathrm{pH} 7.4$ 108 by making a solution containing $1 \%(\mathrm{w} / \mathrm{v})$ soybean proteins and $6 \%(\mathrm{w} / \mathrm{v})$ glucose. The reaction systems in closed falcon tubes were incubated in a water bath at $70^{\circ} \mathrm{C}$ for up to $48 \mathrm{~h}$.

110 A reaction system without glucose was used as control. At different time periods, samples were retrieved from the water bath and placed in an ice bath to stop the reaction. Further, the

112 modified protein solutions were immediately used for the determination of reactive lysine residues, protein bound carbonyls and free amino groups. Aliquots for SDS-PAGE were 114 frozen at $-20^{\circ} \mathrm{C}$ until further use.

\section{Maillard reaction in the presence of soluble wheat proteins}

Two types of model systems were considered. One model system contained $0.25 \%$ $(\mathrm{w} / \mathrm{v})$ of soybean proteins with $0.75 \%(\mathrm{w} / \mathrm{v})$ of wheat proteins and $6 \%(\mathrm{w} / \mathrm{v})$ of glucose in the 
118 same $0.1 \mathrm{M}$ phosphate buffer $\mathrm{pH}$ 7.4. Another model system contained $0.5 \%(\mathrm{w} / \mathrm{v})$ soybean proteins with $0.5 \%(\mathrm{w} / \mathrm{v})$ wheat proteins and $6 \%(\mathrm{w} / \mathrm{v})$ glucose. Respective model systems

120 without glucose were prepared as control. Further these systems were treated similarly as the model systems containing no soluble wheat proteins.

\section{Assessment of the Maillard reaction}

\section{Determination of protein bound carbonyls}

124 Protein bound carbonyls were measured after converting them to the corresponding 2, 4- dinitrophenylhydrazones. Briefly, $300 \mu$ protein solution was incubated with $400 \mu 12.4$ 126 dinitrophenylhydrazine (DNPH) $10 \mathrm{mM}$ in $2 \mathrm{M} \mathrm{HCl}$. Further, the proteins were precipitated with $10 \%$ trichloroacetic acid (final concentration) and thoroughly washed with $1 \mathrm{ml}$ 128 ethanol/ethyl acetate (1:1) after derivatization; hence any unreacted DNPH or DNPH bound to any other components than protein was removed. Finally the pellet was redissolved in $8 \mathrm{M}$

130 urea and absorbance was measured at $370 \mathrm{~nm}$ using a Bio-Rad Benchmark Plus microplate spectrophotometer (Nazareth, Belgium). The carbonyl content was calculated using a molar 132 absorption coefficient of $22000 \mathrm{M}^{-1} \mathrm{~cm}^{-1}$ (Levine et al. 1994).

\section{Loss of reactive lysine residues}

134 The loss of reactive lysine residues was monitored using derivatization with orthophthaldialdehyde (OPA) in the presence of 2-mercaptoethanol which yields a fluorescent 136 product with a maximum excitation wavelength of $340 \mathrm{~nm}$ and emission of $450 \mathrm{~nm}$ using a Spectramax Gemini XPS fluorimeter from Molecular Devices (Brussels, Belgium) (Ferrer et 138 al. 2003). A standard of $\beta$-casein was used to prepare a calibration curve and samples were pre-treated and analyzed using a fluorimeter as previously described (Morales et al. 1996). 
Protein cross-linking or fragmentation was analyzed by SDS-PAGE under reducing

142 conditions. A 4\% acrylamide stacking gel and a 10\% acrylamide resolving gel were used for protein separation. An aliquot of $10 \mu \mathrm{L}$ sample containing $6 \mu \mathrm{g}$ of protein was added to $10 \mu \mathrm{l}$

144 Laemmli sample buffer containing $\beta$-mercaptoethanol and heated at $95^{\circ} \mathrm{C}$ for $5 \mathrm{~min}$. The samples were further loaded on the gel along with the molecular weight marker. Precision

146 plus protein unstained standard was used as a reference to determine the molecular weight of proteins of interest. Krypton fluorescence staining was used for bands visualization. The gels

148 were further read using the Molecular Imager PharosFX Plus from Bio Rad (Nazareth, Belgium) where the molecular weights of the proteins were recorded.

\section{Protein determination}

Protein determination was performed by determining the nitrogen content according to 152 the Kjeldahl procedure (AOAC Official Method 981.10 1981). A multiplication factor of 5.71 was used to convert nitrogen content to soybean protein content, and a factor of 6.25 to

154 convert to soybean protein content for the mixtures of soybean and wheat protein. The non protein nitrogen (NPN) fraction was determined in the supernatant after a previous protein 156 precipitation with $15 \%$ TCA (final concentration).

\section{ELISA assays}

158 Samples of the above-described model systems were analyzed using different commercial ELISA kits: Veratox ${ }^{\circledR}$ Soy Allergen, BioKits Soya Allergen and Soy Residue.

160 These samples include the glucose-free model system containing only soybean proteins (system 1), the model system containing soybean proteins with glucose (system 2), the two 162 model systems containing different ratio's of soybean proteins and soluble wheat proteins $(0,5 \%$ soybean proteins $+0,5 \%$ soluble wheat proteins (system 3$)$ and $0,25 \%$ soybean proteins 
$164+0,75 \%$ soluble wheat proteins (system 4), respectively) and the two model systems 3 and 4 containing different ratio's of soybean proteins and soluble wheat proteins, in the addition of

$1666 \%$ glucose ((system 5) resp. (system 6)). Of the different model systems, samples retrieved after 0,24 and $48 \mathrm{~h}$ incubation at $70^{\circ} \mathrm{C}$ were analyzed. The untreated sample $(=0$ hours of 168 thermal treatment) of the glucose-free model system (1) containing only soybean proteins is referred to as the reference sample. For each sample of the different model systems a dilution

170 series was made $(0-50-100-500-1500-1500 \mathrm{ng} / \mathrm{ml}$ soybean protein $)$ in the extraction buffer/dilution solution of the respective kit. For the BioKits Soya Allergen Assay additional

172 dilutions had to be analyzed. The actual concentrations are the concentrations of soybean proteins based on the absolute protein determination using the Kjeldahl procedure and do not

174 include the wheat proteins that were added in some of the model systems. The dilution series were analyzed in duplo in a similar manner as sample extracts according to the respective 176 manufacturers' manuals. Absorbance measurements were made in a microtiter plate reader (Multiskan MCC/340, Titertek, Huntsville, Alabama). Each kit was calibrated using the

178 respective standard protein solutions included in each kit. The absorbance values were fitted to the protein concentration of the standard solutions, according to a four-parameter-logistic

180 dose-response curve corresponding to following equation (2.1). This equation presents a standard way for the expression of immunoassay data, where $a$ is the maximum dose (protein 182 concentration), $b$ is the minimum concentration, $c$ is the $\mathrm{E}_{50}$-value (concentration at halfmaximal saturation), $d$ is the slope of the curve and conc is the concentration of the standard 184 or sample.

$$
\text { Absorbance }=\left[\frac{(b-a)}{\left(1+\frac{\text { conc }}{c}\right) \wedge d}\right]+a
$$


186 Only the data obtained within the range of the respective standard curve were considered in the results. In case of the Veratox ${ }^{\circledR}$ Soy Allergen kit, the kit's procedure 188 prescribes to fit the data to log-logit function, which is a linearization of the four-parameter logistic function. For the Soy Residue and the BioKits Soya Allergen Assay no suggestion is 190 made as to which function to use to fit the data. Data above or below the calibration range are indicated by an asterisk $\left(^{*}\right)$ or a 'zero' (0), respectively, in the charts. 


\section{Results}

\section{Progress of the Maillard reaction}

An increase in protein bound carbonyl amounts as result of the incubation in the

198 increase was observed. Similarly, an increase in protein bound carbonyls was observed when soluble wheat proteins were added to the model systems. After $48 \mathrm{~h}$ incubation with glucose a

2007 fold increase in protein bound carbonyls was observed in the case of the model system containing $0.5 \%$ soybean proteins. For the model system containing $0.25 \%$ soybean proteins a

2024 fold increase was observed.

Further, changes in the reactive lysine residues have been recorded. About $80 \%$

204 decrease of reactive lysine residues has been recorded upon incubation of $1 \%$ soybean proteins with glucose (Figure 2). Interestingly, a 23\% decrease in reactive lysine residues

206 after $6 \mathrm{~h}$ incubation in the absence of glucose was also recorded. A further decrease in reactive lysine residues was however not recorded, while in the presence of glucose, a steady

208 decrease was obtained throughout the whole incubation experiment. Further, about $90 \%$ of the reactive lysine residues were modified in the model system containing $0.5 \%$ soybean proteins

210 after $48 \mathrm{~h}$ of incubation with glucose while for the model system containing $0.25 \%$ soybean proteins almost all the reactive lysine residues were modified.

212 Figure 3 shows the SDS-PAGE pattern of the native and glycated soybean proteins. Changes in the SDS-PAGE pattern of the soybean proteins incubated in the absence of

214 glucose were observed (lane 1-3). The intensity of the bands representing the $\alpha$-, $\alpha$ - and $\beta$ chain of the Gly m 5 allergen with the molecular weight of 70, 74 and 50kDa respectively, 216 decreased markedly with the incubation time (I.U.I.S.Allergen Nomenclature 2009; 
UniProtKB/Swiss-Prot 2010). However, the acid and basic subunits of the Gly $m 6$ allergen

218 (32 and $19 \mathrm{kDa}$, respectively) remained stable upon the whole incubation time. More severe changes were observed however, in the SDS-PAGE pattern of the soybean proteins incubated

220 with glucose either in the presence or absence of soluble wheat proteins. Most of the allergenic proteins have been affected as manifested by the loss of intensity of their respective

222 bands. Similarly as with the incubation in the absence of glucose, the $\alpha-, \alpha^{\prime}-$ and $\beta$-chain of the Gly $m 5$ allergen were affected the most with the acid and basic subunits of the Gly $m 6$ 224 allergen being the most resistant. The respective bands of the Gly $m 6$ allergen were still visible after $24 \mathrm{~h}$ incubation in the presence of glucose although with slightly fainted 226 intensity. All the other proteins were highly modified as evidenced by the smearing towards the top of the gel which progressed with the incubation time. After $48 \mathrm{~h}$ of incubation with 228 glucose only the bands corresponding to the acid and basic subunits of the Gly $m 6$ allergen were still slightly visible. Aggregates with masses of over $300 \mathrm{kDa}$ were also formed which 230 hindered their migration into the resolving gel.

\section{Detection with commercial ELISA kits}

232 The soybean protein concentration of the standards provided by each individual kit is expressed in parts per million (ppm) which equals ng analyte $\mathrm{mg}^{-1}$ of food product. When

234 testing the commercial kits, the objective was to compare the actual soybean protein concentration of the analyzed samples with the measured concentration, derived from the 236 calibration curve obtained with the kit's standards. To this end, the concentration of the kits standards was converted to the same dimension of that from the model system samples. This 238 was done according to formula 3.1, considering the weight of the sample (mg) extracted by a particular volume of extraction buffer $(\mathrm{mL})$. 


$$
\frac{n g \text { analyte }}{m g \text { food }}(p p m) \times \frac{\text { weight of extracted sample }(\mathrm{mg})}{\text { volume of extraction buffer used }(\mathrm{ml})}=\frac{n g \text { analyte }}{\mathrm{ml} \text { solution }}
$$

For the evaluation of the kits performance, dilution series of the soy protein solutions

244 obtained from the six different model systems were applied in the appropriate concentration range of each kit. The obtained absorbance values were converted to a measured soy protein 246 concentration, which was compared with the actual protein concentration presents in each diluted solution (Figure 4).

248 Biokits Soya Allergen

With the standard solutions included in the BioKits Soya Allergen assay, a calibration 250 curve was constructed according to the four-parameter logistic model, ranging from zero to $200 \mathrm{ng} \mathrm{mL}^{-1}$ soybean protein. The soybean protein concentration in the reference samples was

252 overestimated on average by $290 \%$ in a concentration dependent manner (Figure 4A). Therefore, at the highest concentrations absorbance values exceeding those obtained in the 254 calibration curve were observed. Upon heating at $70^{\circ} \mathrm{C}$ without glucose for $24 \mathrm{~h}$ the signal decreased with $14 \%$ (not shown) and an additional $8 \%$ when the treatment was extended up to

$25648 \mathrm{~h}$. When soluble wheat proteins were added to the model system the average overestimation of the concentration of the samples was diminished to $250 \%$, irrespective the

258 soy/wheat protein ratio. However, at the lowest soybean/wheat protein ratio, a sharper decline in the measured soybean protein concentration was observed upon heating; after $48 \mathrm{~h}$ the 260 signal dropped on average $38 \%$ ( $0.75 \%$ soluble wheat proteins) compared to an average of $27 \%(0.5 \%$ soluble wheat proteins, not shown). Addition of glucose resulted in a further

262 decrease of the measured concentration compared to the samples treated without glucose; the signal was declined with $60 \%$ after $48 \mathrm{~h}$ heat-treatment. 
A calibration curve was established with the standard solutions provided in the 266 Veratox ${ }^{\circledR}$ Soy Allergen kit. The standard consists of Soy Protein Isolate and covers a range from zero to $4000 \mathrm{ng} \mathrm{mL}^{-1}$ after conversion of the concentration expressed in $\mathrm{ng} \mathrm{g}^{-1}$, 268 according to formula 3.1. As can be observed from Figure 4B, the actual soybean protein concentration present in the reference solution and its dilutions was highly overestimated on 270 average by $300 \%$. Therefore, the obtained absorbance values for the reference samples with 1500 and $1000 \mathrm{ng} \mathrm{mL}^{-1}$ soybean protein were beyond the range of the calibration curve and 272 were not included in Figure 4B. Upon the presence of soluble wheat proteins in the model system the overestimation was even increased up to on average $400 \%(0.5 \%$ soybean protein $274+0.5 \%$ soluble wheat proteins, not shown $)$ or on average $600 \%(0.25 \%$ soybean proteins + $0.75 \%$ soluble wheat proteins). However, already after heating the reference sample for $24 \mathrm{~h}$ 276 in the absence of glucose the signal disappeared completely. In the presence of soluble wheat proteins only $1 \%(0.5 \%$ soluble wheat proteins $)$ or $8 \%(0.75 \%$ soluble wheat proteins $)$ of the 278 soybean proteins was detected after $24 \mathrm{~h}$ heating (not shown) and extension to $48 \mathrm{~h}$ lead to a complete loss of signal. Heating the proteins in the presence of glucose confirmed the lack of 280 robustness of the kits.

\section{Soy Residue}

282 In the Soy Residue assay the soybean trypsin inhibitor is used as the analytical target. The kit includes standard solutions containing 5, 2.5, 1 and 0 ppm soybean protein 284 corresponding to $500,250,100$ and $0 \mathrm{ng} \mathrm{mL}^{-1}$ soybean protein after conversion which were used to construct a four-parameter logistic calibration curve. The 5 and $2.5 \mathrm{ppm}$ standards 286 returned equal absorbance values, amounting 2.8-3, consequently quantification can only be performed up to a level of $2.5 \mathrm{ppm}$. In addition, the $1 \mathrm{ppm}$ standard, being the lowest standard containing the analyte, returned a quite high absorbance value of 2.5. Therefore, it was 
decided to dilute the available standards provided with the kit in order to obtain a more 290 suitable calibration curve. The protein concentration of the native reference sample was underestimated for the samples containing 50 and $100 \mathrm{ng} \mathrm{mL} L^{-1}$ soybean protein in a 292 concentration depend manner with on average 12\% (Figure 4C). Exceeding the calibration range, the reference samples containing 500, 1000 and $1500 \mathrm{ng} \mathrm{mL}^{-1}$ soybean protein could 294 not be considered and the latter two were not included in Figure 4C. Upon heating without glucose for $24 \mathrm{~h}$ at $70^{\circ} \mathrm{C}$, only about $2 \%$ of the proteins could be detected (not shown) with an 296 additional decrease to only $1 \%$ when extended to $48 \mathrm{~h}$. When soluble wheat proteins were added to the system, the measured concentration was lower compared to the reference sample $298(15-20 \%)$; in contrast to the observations described for the Veratox ${ }^{\circledR}$ Soy Allergen, a lower signal was measured when more wheat proteins were added. Also here an almost complete 300 loss of signal was observed after heating in the presence of soluble wheat proteins, with only $1 \%$ of the soybean proteins being detected after $24 \mathrm{~h}$ (not shown) and $0.2 \%$ after $48 \mathrm{~h}$. 302 Similarly, no additional effect of adding glucose during the heat-treatment could be seen. 


\section{Discussion}

304 In this study, different commercial ELISA kits for the detection of soy proteins and the influence of protein glycation hereon was investigated. Application of the reference soybean 306 protein solution in the various kits resulted in an extreme overestimation of the actual protein concentration in the Veratox Soy Allergen and BioKits Soya assays, while for the Soy 308 Residue assay an underestimation was recorded. In addition, the amount of soybean proteins that was measured was dependent on the concentration in the sample that was applied. Similar

310 observations have been made in a validation study of five commercial ELISA kits for peanut detection (Poms et al. 2005). A possible explanation for the differences between the actual 312 and the measured soybean protein concentration that were obtained with the different kits could be found in the nature of the standard solutions of the respective kits. In the Soy

314 Residue kit a single protein, namely the Soy Trypsin Inhibitor, is used as the target analyte. Possibly the factor used to convert the soy trypsin inhibitor concentration to total soy protein

316 concentration is not the same as the actual proportion soy trypsin inhibitor present in the soybean protein extract used in this study. Strategically, the choice for a single marker protein

318 for the detection of soybean proteins in processed food products is especially risky in terms of susceptibility to protein modification and its impact on the detection, as was moreover

320 demonstrated in this study. The high overestimation of the actual soy protein with the BioKits Soya Allergen assay demonstrate that the antibodies that are used to develop the assay 322 recognize better the proteins that are present in the soybean protein extract used in this study than the ones present in the standard solutions of the kit. This could be due to the use of 324 different soybean varieties to produce the protein extract. Immunochemical activity of peanut proteins has also been shown to depend on the peanut variety that is used (De Meulenaer et al. 326 2005). These observations indicate that the test results heavily depend on the assay that is 
used and urge the need for reference materials for the development and validation of standardized methods.

Upon heating the reference soybean protein solution in absence of glucose, a decreased

330 detection was observed in the BioKits Soya Allergen, however, still overestimating the actual soybean protein concentration. In contrast, both the Veratox Soy Allergen and the Soy

332 Residue assay lacked total robustness. The complete loss of detectability can probably be due to the denaturation of soybean proteins especially because only minor changes in terms of

334 formation of protein carbonyls and losses of lysine residues were observed as compared to the changes observed in the model systems containing glucose (Figure 1\&2). However, the 336 observed loss of intensity of the Gly $m 5$ allergen upon heating without glucose, indicating denaturation, might explain the lowered detection by the BioKits Soya Allergen Assay

338 (Kitabatake et al. 1989). The Gly $m 6$ allergen, with a denaturation temperature of about $90^{\circ} \mathrm{C}$ could then account for the remaining detection. The Soy Trypsin Inhibitor shows a thermal

340 transition at $60-65^{\circ} \mathrm{C}$ which could explain the decreased detection with the Soy Residue assay after heating at $70^{\circ} \mathrm{C}$ (Roychaudhuri et al. 2004). Although the denaturation of this protein has

342 been shown to be reversible, fast cooling of the model systems, by putting the samples on ice after heat-treatment, could have prevented a proper refolding.

344 When soybean proteins are present in a food product, protein cross-linking can occur with other (bulk) proteins, which could have an additional impact on the detection. Therefore

346 the impact of heating soybean proteins in the presence of soluble wheat proteins was investigated as well. In a previous study on hazelnut proteins it was seen that soluble wheat 348 proteins can have an additional impact (manuscript submitted). However, no additional impact on the detection of soybean proteins was seen when soluble wheat proteins were added 350 to the model systems. 
During heating of the reference soybean proteins with glucose either with our without 352 soluble wheat proteins, changes on molecular level took place as evidenced by a number of parameters investigated (Figure 1-3). As a consequence, these changes on protein level led to 354 further decreases in detectability especially for the BioKits Soya Allergen Assay. Nevertheless, in the same kit, additional protein cross-linking with other soluble wheat 356 proteins via the produced protein bound carbonyls during glycation, did not further affect the detectability of the soybean proteins. As a complete lack of robustness of the Veratox Soy 358 Allergen and the Soy Residue was observed upon heating soybean proteins alone, no additional impact of their heating with glucose either in the presence or absence of soluble 360 wheat proteins could be seen.

The results presented show that the detection of soybean proteins by means of 362 commercial ELISA kits is strongly influenced by processing. This implies that certain assays could falsely declare a processed food product as "free of soybean proteins", while soybean

364 proteins might still be present. Consequently, this holds a risk for the allergic consumer. In the same time some other kits, such as BioKits Soya Allergen and Veratox Soy Allergen, show 366 strong overestimation especially for the native soybean proteins which presents risks for the food industry where the product withdrawal from the market is based on the results obtained 368 with similar commercial kits. In conclusion, there is still a lack of sensitive analytical methods for the detection of traces of allergens in processed foods and thus controls cannot be carried 370 out in a reliable way. Moreover, in this study, by inducing Maillard reaction in soybean proteins in a buffered system, abstraction of possible consequences of protein insolubility and 372 eventual extractability was made. This implies that, within a real food product, it might be expected that estimations of the contamination levels would be even more severely affected. It 374 should therefore be emphasized that the tested ELISA assays can be useful to give an indication of the presence of contaminants, rather than an exact quantitative value of the 
376 contamination level. But even if such assays are used in a mere qualitative context, outmost care should be given with respect to the interpretation of the results. 


\section{Acknowledgements}

This work was funded by the Belgian Science Policy (BELSPO) (contract $\mathrm{n}^{\circ}$ $\mathrm{SD} / \mathrm{AF} / 03 \mathrm{~A})$. The authors would like to thank the Neogen Corporation for kindly providing 382 us the Veratox Soy Allergen ELISA kits for this study.

1
1
1
1
1
2
2
2
2
2
2
2
2
2
2
3
3
3
3
3
3
3
3
3
3
4
4
4
4
4
4
4
4
4
4
5
5
5
5
5
5
5
5




\section{References}

386 AOAC Official Method 981.10. 1981. Crude Protein in Meat: Block Digestion Method. Official Methods of Analysis of AOAC, 16th edition.

388 Arita, K., Babiker, E.E., Azakami, H. and Kato, A. 2001. Effect of chemical and genetic attachment of polysaccharides to proteins on the production of IgG and IgE. Journal of $390 \quad$ Agricultural and Food Chemistry 49, 2030-2036.

Babiker, E.E., Hiroyuki, A., Matsudomi, N., Iwata, H., Ogawa, T., Bando, N. and Kato, A. 392 1998. Effect of polysaccharide conjugation or transglutaminase treatment on the allergenicity and functional properties of soy protein. Journal of Agricultural and Food Chemistry 46, 866-871.

Ballmer-Weber, B.K. and Vieths, S. 2008. Soy allergy in perspective. Current Opinion in Allergy and Clinical Immunology 8, 270-275.

Bando, N., Tsuji, H., Hiemori, M., Yoshizumi, K., Yamanishi, R., Kimoto, M. and Ogawa, T. 398 1998. Quantitative analysis of Gly $\mathrm{m} \mathrm{Bd} 28 \mathrm{~K}$ in soybean products by a sandwich enzyme-linked immunosorbent assay. Journal of Nutritional Science and Vitaminology 44, 655-664.

Bjorksten, F., Halmepuro, L., Hannuksela, M. and Lahti, A. 1980. Extraction and properties 402 of apple allergens. Allergy 35, 671-677.

Burks, A.W., Williams, L.W., Helm, R.M., Thresher, W., Brooks, J.R. and Sampson, H.A. 404 1991. Identification of Soy Protein Allergens in Patients with Atopic-Dermatitis and Positive Soy Challenges - Determination of Change in Allergenicity After Heating Or Enzyme Digestion. PLENUM PRESS DIV PLENUM PUBLISHING CORP, NEW YORK.

Codina, R., Oehling, A.G. and Lockey, R.F. 1998. Neoallergens in heated soybean hull. International Archives of Allergy and Immunology 117, 120-125.

410 de Lagemaat, J.V., Silvan, J.M., Moreno, F.J., Olano, A. and del Castillo, M.D. 2007. In vitro glycation and antigenicity of soy proteins. Food Research International 40, 153-160.

De Meulenaer, B., De la Court, Acke, D., De Meyere, T. and Van de Keere, A. 2005. Development of an enzyme-linked immunosorbent assay for peanut proteins using 414 chicken immunoglobulins. Food and Agricultural Immunology 16, 129-148.

European Parliament and Council Directive 2007/68/EC. 2007. Amending Directive 2000/12/EC as regards the indication of the ingredients present in foodstuffs. Official Journal of the European Eunion 2007 L310, 11-14.

418 Ferrer, E., Alegria, A., Farre, R., Abellan, P., Romero, F. and Clemente, G. 2003. Evolution of available lysine and furosine contents in milk-based infant formulas throughout the shelf-life storage period. Journal of the Science of Food and Agriculture 83, 465-472. 
422

424

Foucard, T. and Yman, I.M. 1999. A study on severe food reactions in Sweden - is soy protein an underestimated cause of food anaphylaxis? Allergy 54, 261-265.

Frias, J., Song, Y.S., Martinez-Villaluenga, C., de Mejia, E.G. and Vidal-Valverde, C. 2008. Immunoreactivity and amino acid content of fermented soybean products. Journal of Agricultural and Food Chemistry 56, 99-105.

I.U.I.S.Allergen Nomenclature. 2009. http://www.allergen.org/.

Kitabatake, N., Tahara, M. and Doi, E. 1989. Denaturation Temperature of Soy Protein Under Low Moisture Conditions. Agricultural and Biological Chemistry 53, 1201-1202.

Kleine-Tebbe, J., Wangorsch, A., Vogel, L., Crowell, D.N., Haustein, U.F. and Vieths, S. 2002. Severe oral allergy syndrome and anaphylactic reactions caused by a Bet v 1related PR-10 protein in soybean, SAM22. Journal of Allergy and Clinical Immunology 110, 797-804.

Levine, R.L., Williams, J.A., Stadtman, E.R. and Shacter, E. 1994. Carbonyl Assays for Determination of Oxidatively Modified Proteins.

Mittag, D., Vieths, S., Vogel, L., Becker, W.M., Rihs, H.P., Helbling, A., Wuthrich, B. and Ballmer-Weber, B.K. 2004. Soybean allergy in patients allergic to birch pollen: Clinical investigation and molecular characterization of allergens. Journal of Allergy and Clinical Immunology 113, 148-154.

Monaci, L., Tregoat, V., van Hengel, A.J. and Anklam, E. 2006. Milk allergens, their characteristics and their detection in food: A review. European Food Research and Technology 223, 149-179.

Morales, F.J., Romero, C. and Jimenezperez, S. 1996. Evaluation of heat-induced changes in Spanish commercial milk: Hydroxymethylfurfural and available lysine content. International Journal of Food Science and Technology 31, 411-418.

Muller, U., Luttkopf, D., Hoffmann, A., Petersen, A., Becker, W.M., Schocker, F., Niggemann, B., Altmann, F., Kolarich, D., Haustein, D. and Vieths, S. 2000. Allergens in raw and roasted hazelnuts (Corylus avellana) and their cross-reactivity to pollen. European Food Research and Technology 212, 2-12.

Poms, R.E., Agazzi, M.E., Bau, A., Brohee, M., Capelletti, C., Norgaard, J.V. and Anklam, E. 2005. Inter-laboratory validation study of five commercial ELISA test kits for the determination of peanut proteins in biscuits and dark chocolate. Food Addit. Contam 22, 104-112.

Report of the FAO. 1995. Technical Consultation on Food Allergies. Food and Agricultural Organization of the United Nations.

Roychaudhuri, R., Sarath, G., Zeece, M. and Markwell, J. 2004. Stability of the allergenic soybean Kunitz trypsin inhibitor. Biochimica et Biophysica Acta-Proteins and Proteomics 1699, 207-212.

Tsuji, H., Okada, N., Yamanishi, R., Bando, N., Ebine, H. and Ogawa, T. 1997. Fate of major soybean allergen Gly m BD 30K in rice-, barley- and soybean-koji miso (fermented 
460 soybean paste) during fermentation. Food Science and Technology International 3, 145-149.

462 Tsuji, H., Okada, N., Yamanishi, R., Bando, N., Kimoto, M. and Ogawa, T. 1995. Measurement of Gly-M-Bd-30K, A Major Soybean Allergen, in Soybean Products by

464 A Sandwich Enzyme-Linked-Immunosorbent-Assay. Bioscience Biotechnology and Biochemistry 59, 150-151.

466 UniProtKB/Swiss-Prot. 2010. http://expasy.org/sprot/.

Wilson, S., Blaschek, K. and de Mejia, E.G. 2005. Allergenic proteins in soybean: Processing $468 \quad$ and reduction of P34 allergenicity. Nutrition Reviews 63, 47-58.

Yamanishi, R., Huang, T., suji, H., ando, N., imoto, M. and gawa, T. 1995. Reduction of 470 soybean allergenicity by fermentation with Bacillus nato. Food Science and Technology International 1, 14-17.

472 Yeung, J.M. and Collins, P.G. 1996. Enzyme immunoassay for determination of peanut proteins in food products. Journal of Aoac International 79, 1411-1416.

474

476

478

480

482

484

486 


\section{$488 \quad$ Figure captions}

Figure 1 Formation of protein bound carbonyls in soybean protein in the presence or absence 490 of soluble wheat proteins due to incubation with glucose. The data points represent mean values \pm SD of three independent determinations. $\square 1 \%$ soybean proteins with $6 \%$ glucose; $\circ$ $4920.5 \%$ soybean with $0.5 \%$ soluble wheat proteins and $6 \%$ glucose; $\Delta 0.25 \%$ soybean and $0.75 \%$ soluble wheat proteins and $6 \%$ glucose; $\diamond 1 \%$ soybean proteins

494 Figure 2 Loss of available lysine due to incubation of soybean proteins in the presence or in the absence of soluble wheat proteins with glucose, data points represent mean values \pm SD of 496 four independent determinations. $\square$ 1\% soybean proteins with $6 \%$ glucose; $\circ 0.5 \%$ soybean with $0.5 \%$ soluble wheat proteins and $6 \%$ glucose; $\Delta 0.25 \%$ soybean and $0.75 \%$ soluble wheat 498 proteins and $6 \%$ glucose; $\diamond 1 \%$ soybean proteins

Figure 3 SDS-PAGE pattern of the soybean proteins incubated in the presence or absence of 500 wheat proteins with glucose Lanes 1-3: $1 \%$ soybean proteins non-treated, $24 \mathrm{~h}$ and $48 \mathrm{~h}$ incubated resp.; lanes 4-6: $1 \%$ soybean proteins and $6 \%$ glucose non-treated, $24 \mathrm{~h}$ and $48 \mathrm{~h}$ 502 incubated resp.; lanes 7-9: $0.5 \%$ soybean proteins with $0.5 \%$ wheat proteins and $6 \%$ glucose non-treated, $24 \mathrm{~h}$ and $48 \mathrm{~h}$ incubated resp.; lanes 10-12: $0.25 \%$ soybean proteins with $0.75 \%$ 504 wheat proteins and $6 \%$ glucose non-treated, $24 \mathrm{~h}$ and $48 \mathrm{~h}$ incubated resp.; MWM molecular weight marker

506 Figure 4 Ratio of measured over actual soybean protein concentration in different ELISA kits of a dilution series of a reference soybean protein solution and after heating in the presence or 508 absence of glucose and soluble wheat proteins. $*^{*}=$ absorbance value of sample above the calibration range, $0=$ absorbance value of sample below the calibration range)

$510 \square$-reference sample, $\square$-reference heated for $48 \mathrm{~h}, \square$-reference heated for $48 \mathrm{~h}$ in the presence of glucose, $\square-0.25 \%$ soybean proteins and $0.75 \%$ soluble wheat proteins, $\square-0.25 \%$ soybean 
7

8

9

11

12

13

14

15

16

17

18

19

20

21

22

23

24

25

26

27

28

29

30

31

32

33

34

35

36

37

38

39

40

41

42

43

44

45

46

47

48

49

50

51

52

53

54

55

56

57

58

59

60

512 proteins and $0.75 \%$ soluble wheat proteins heated for $48 \mathrm{~h}, \square-0.2 \%$ soybean proteins and $0.75 \%$ soluble wheat proteins heated for $48 \mathrm{~h}$ in the presence of glucose

\section{4}

10

3

5

(1)

(1)




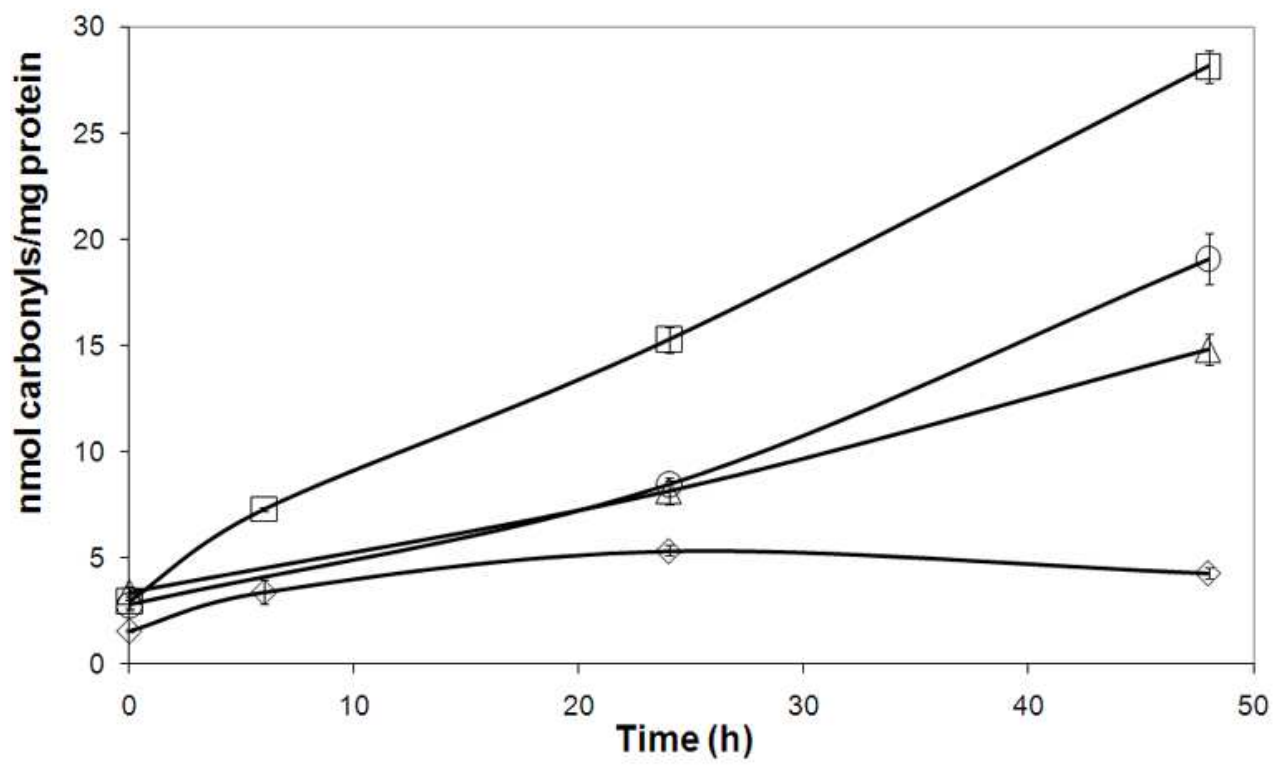

Figure 1 Formation of protein bound carbonyls in soybean protein in the presence or absence of soluble wheat proteins due to incubation with glucose. The data points represent mean values \pm SD of three independent determinations. $\square 1 \%$ soybean proteins with $6 \%$ glucose; $\circ 0.5 \%$ soybean with $0.5 \%$ soluble wheat proteins and $6 \%$ glucose; $\Delta 0.25 \%$ soybean and $0.75 \%$ soluble wheat proteins and $6 \%$ glucose; $\diamond 1 \%$ soybean proteins 


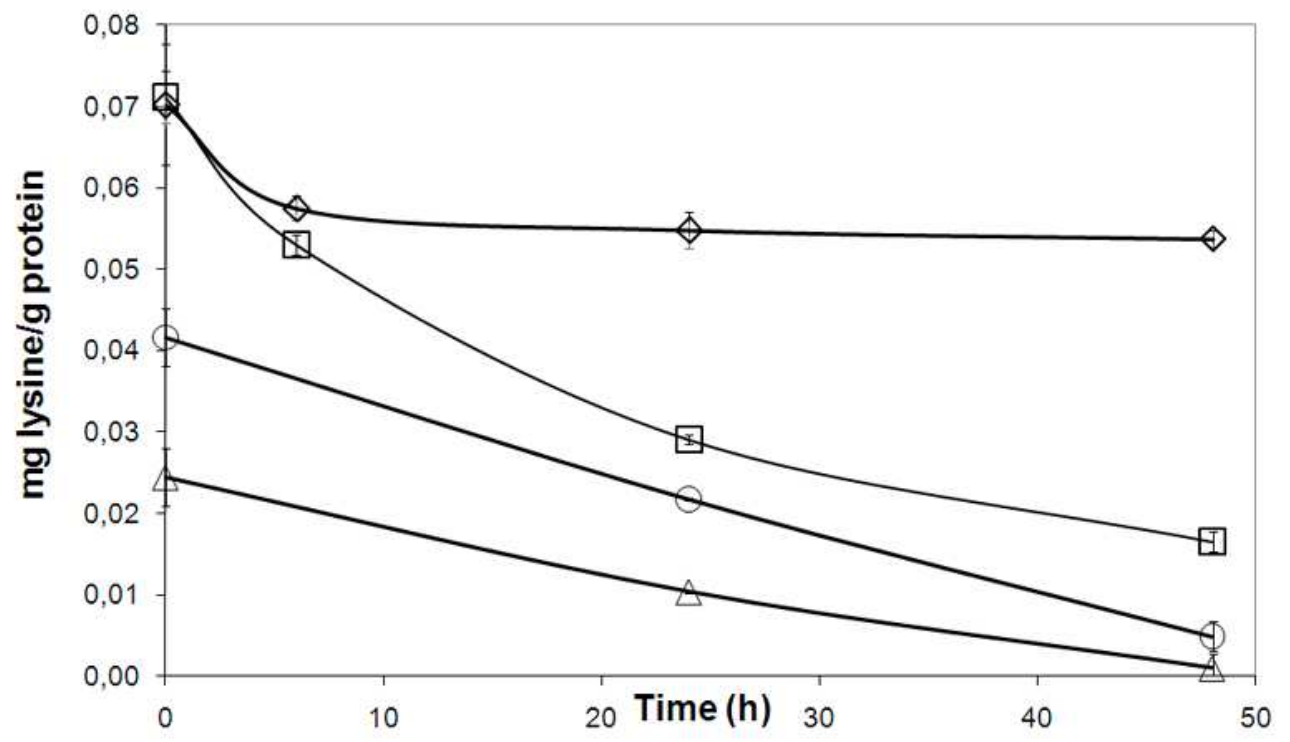

Figure 2 Loss of available lysine due to incubation of soybean proteins in the presence or in the absence of soluble wheat proteins with glucose, data points represent mean values \pm SD of four independent determinations. $\square 1 \%$ soybean proteins with $6 \%$ glucose; $\circ 0.5 \%$ soybean with $0.5 \%$ soluble wheat proteins and $6 \%$ glucose; $\Delta 0.25 \%$ soybean and $0.75 \%$ soluble wheat proteins and $6 \%$ glucose; $\diamond 1 \%$ soybean proteins 
Figure 3 SDS-PAGE pattern of the soybean proteins incubated in the presence or absence of wheat proteins with glucose Lanes 1-3: $1 \%$ soybean proteins non-treated, $24 \mathrm{~h}$ and $48 \mathrm{~h}$ incubated resp.; lanes 4-6: $1 \%$ soybean proteins and $6 \%$ glucose non-treated, $24 \mathrm{~h}$ and $48 \mathrm{~h}$ incubated resp.; lanes 7-9: $0.5 \%$ soybean proteins with $0.5 \%$ wheat proteins and $6 \%$ glucose non-treated, $24 \mathrm{~h}$ and $48 \mathrm{~h}$ incubated resp.; lanes 10-12: $0.25 \%$ soybean proteins with $0.75 \%$ wheat proteins and $6 \%$ glucose non-treated, $24 \mathrm{~h}$ and $48 \mathrm{~h}$ incubated resp.; MWM - molecular weight marker $99 \times 57 \mathrm{~mm}(199 \times 199 \mathrm{DPI})$ 
Figure 4 Ratio of measured over actual soybean protein concentration in different ELISA kits of a dilution series of a reference soybean protein solution and after heating in the presence or absence of glucose and soluble wheat proteins. $*^{*}=$ absorbance value of sample above the calibration range, $0=$ absorbance value of sample below the calibration range)

-reference sample, -reference heated for $48 \mathrm{~h}$, -reference heated for $48 \mathrm{~h}$ in the presence of glucose, $-0.25 \%$ soybean proteins and $0.75 \%$ soluble wheat proteins, $-0.25 \%$ soybean proteins and $0.75 \%$ soluble wheat proteins heated for $48 \mathrm{~h},-0.2 \%$ soybean proteins and $0.75 \%$ soluble wheat proteins heated for $48 \mathrm{~h}$ in the presence of glucose 
Figure 4 Ratio of measured over actual soybean protein concentration in different ELISA kits of a dilution series of a reference soybean protein solution and after heating in the presence or absence of glucose and soluble wheat proteins. (* $=$ absorbance value of sample above the calibration range, $0=$ absorbance value of sample below the calibration range)

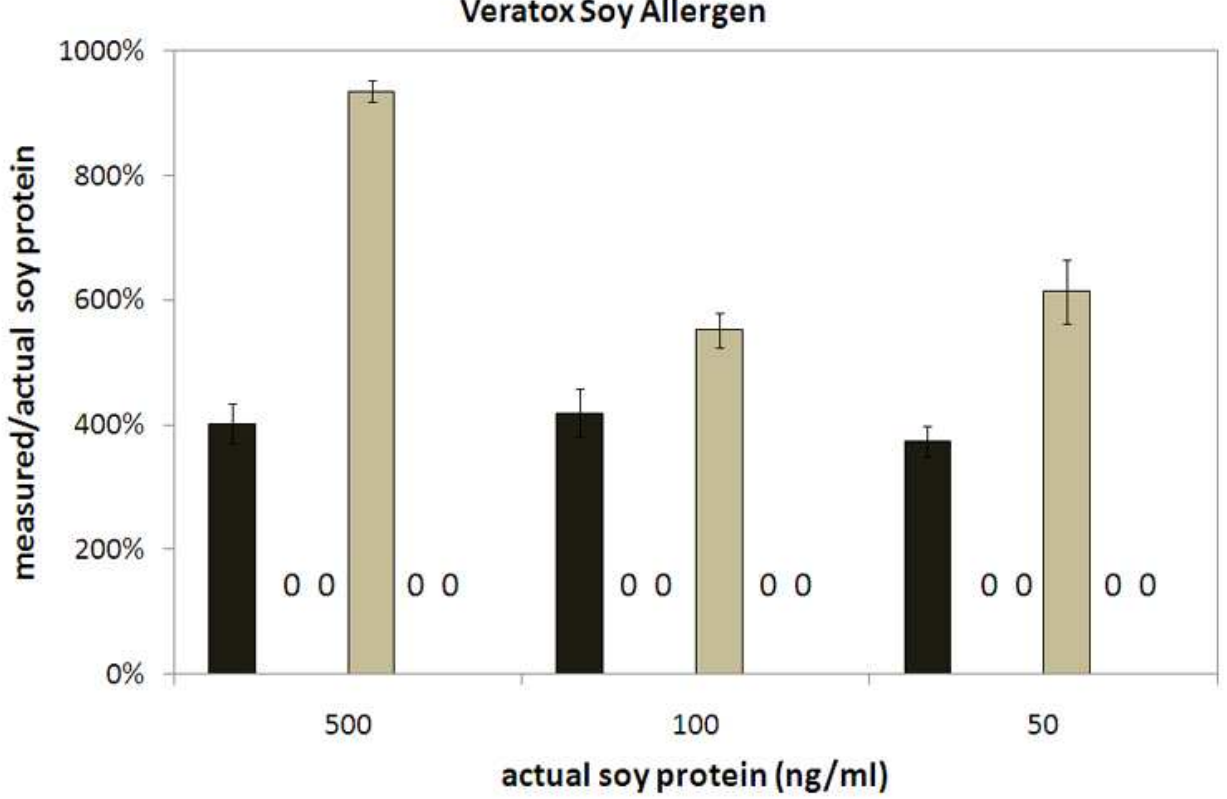

-reference sample, -reference heated for $48 \mathrm{~h}$, -reference heated for $48 \mathrm{~h}$ in the presence of glucose, $-0.25 \%$ soybean proteins and $0.75 \%$ soluble wheat proteins, $-0.25 \%$ soybean proteins and $0.75 \%$ soluble wheat proteins heated for $48 \mathrm{~h}$, $-0.2 \%$ soybean proteins and $0.75 \%$ soluble wheat proteins heated for $48 \mathrm{~h}$ in the presence of glucose 
1

2

3

4

5

6

10

11

12

13

14

15

16

17

18

19

20

21

22

23

24

25

26

27

28

29

30

31

32

33

34

35

36

37

38

39

40

41

42

43

44

45

46

47

48

49

50

51

52

53

54

55

56

57

58

59

60

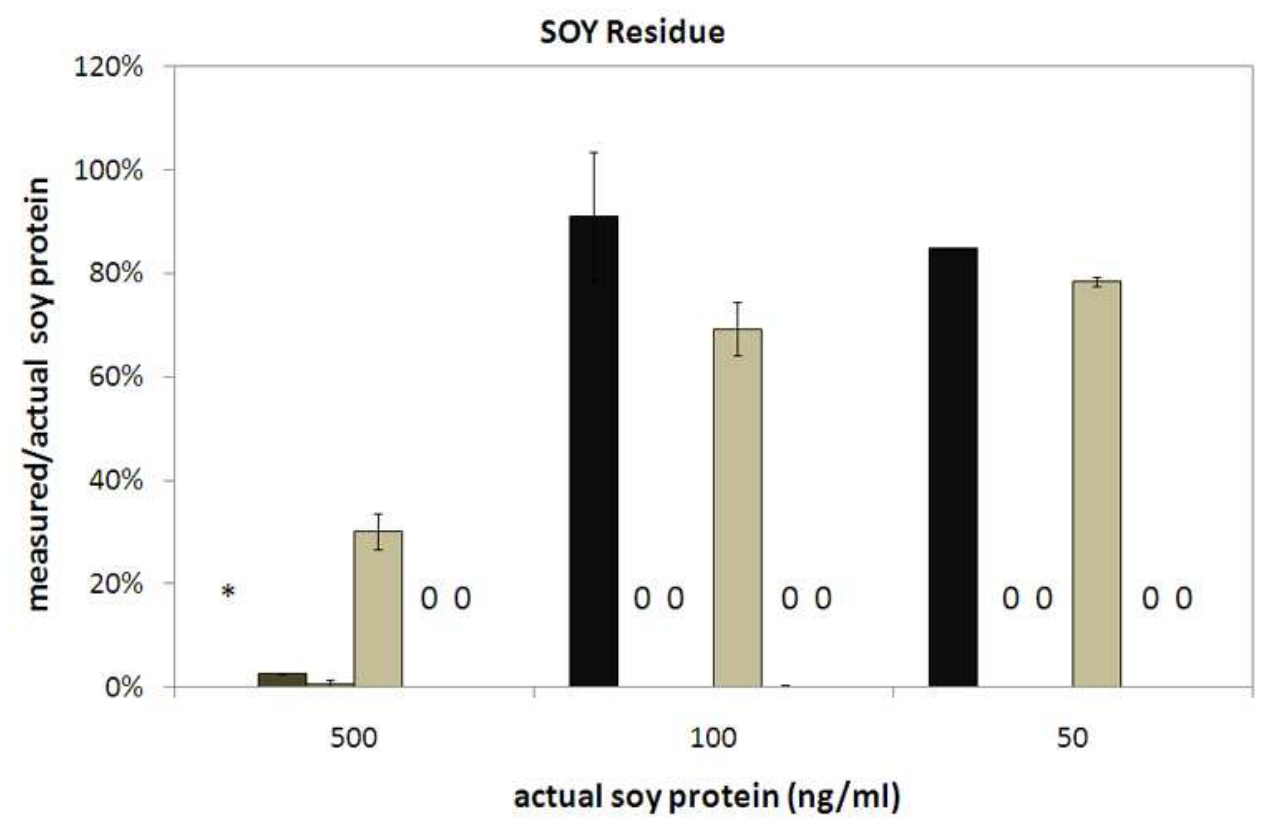

Figure 4 Ratio of measured over actual soybean protein concentration in different ELISA kits of a dilution series of a reference soybean protein solution and after heating in the presence or absence of glucose and soluble wheat proteins. (* ${ }^{*}$ absorbance value of sample above the calibration range, $0=$ absorbance value of sample below the calibration range)

-reference sample, -reference heated for $48 \mathrm{~h}$, -reference heated for $48 \mathrm{~h}$ in the presence of glucose, $-0.25 \%$ soybean proteins and $0.75 \%$ soluble wheat proteins, $-0.25 \%$ soybean proteins and $0.75 \%$ soluble wheat proteins heated for $48 \mathrm{~h}$, $-0.2 \%$ soybean proteins and $0.75 \%$ soluble wheat proteins heated for $48 \mathrm{~h}$ in the presence of glucose 